\title{
The susceptibility testing of 13 strains of Mycobacterium leprae to rifampicin and the determination of minimal effective dosage
}

\author{
WANG HEYING, LI WENZHONG, YE GANYUN, \\ YU LINCHONG \& SHI MEIQIN \\ Department of Leprosy Research, Institute of Dermatology, CAMS, \\ Nanjing, People's Republic of China
}

Accepted for publication 29 March 1991

\begin{abstract}
Summary By use of the mouse footpad technique, the susceptibility testing of 13 strains of Mycobacterium leprae to rifampicin (RFP) and the determination of minimal effective dosage (MED) were carried out. Among these strains of $M$. leprae, 8 were obtained from previously untreated multibacillary leprosy patients and 5 from relapsed leprosy patients without using RFP previously. The results showed that the MED of all strains to RFP were $\leqslant 0.001 \%$ FRP in the diet, 5 strains being equal to $0.001 \%, 5 \leqslant 0.0001 \%, 2 \geqslant 0.0003 \%$ and $1 \leqslant 0.0003 \%$. The results indicated that the MED value of RFP could be lower than that of other reports. Because the critical concentration of RFP for assessment of RFPresistant strains is not well established a further study would be worthwhile. The results of the determination of sera RFP concentrations in mice administered the RFP diet were identical with that of Holmes' report. Five of the 13 strains also showed that the growth of bacilli were suppressed by $10 \mathrm{mg} / \mathrm{kg}$ RFP using the gavage method.
\end{abstract}

\section{Introduction}

Since Opromolla firstly used rifampicin (RFP) to treat patients in 1963, the bactericidal activity of RFP for $M$. leprae was confirmed by many researchers. ${ }^{1-3}$ So far this drug has been used for leprosy in almost every country. With the development of the mouse footpad technique, it has become possible to estimate the minimal effective dosage (MED) of this drug. However, the critical concentration of RFP is not as well established as that of dapsone (DDS), ${ }^{4}$ so that the finding of RFP-resistance could be very difficult, particularly low degree resistance. For studying the sensitivity of $M$. leprae to RFP and the determination of MED suppressing $M$. leprae growth, we collected 13 strains of $M$. leprae from the skin lesions of patients with multibacillary leprosy in leprosaria. This paper reports the activity of RFP against these strains of $M$. leprae and MED in the experiments of mouse footpad. 


\section{Materials and methods}

SOURCE OF M. LEPRAE

A total of 13 strains of $M$. leprae were isolated, of which 8 strains were obtained from previously untreated multibacillary leprosy patients and 5 from relapsed leprosy patients without using RFP previously. The specimens were taken by skin biopsy or by the scrape method.

\section{MOUSE FOOTPAD TECHNIQUE}

The mouse footpad technique for drug susceptibility testing was as described previously. ${ }^{5,6}$ The CFW-strain mice were used in all studies. Inoculation of $1.0 \times 10^{4}$ in both hind footpads was employed. For each of the strains one group of $10 \sim 12$ mice served as untreated control and groups treated $(6 \sim 8$ mice each) were divided into groups of 0.003 , $0 \cdot 001,0.0003$ and $0.0001 \%$ RFP per $100 \mathrm{~g}$ diet. At the same time 5 out of the 13 patient strains were also taken up with $10 \mathrm{mg} / \mathrm{kg}$ RFP once a week by gavage. The drugs were given by the continuous administration method. In the untreated control group $M$. leprae from both rear footpads were harvested at $5 \sim 6$ months after inoculation, at intervals of 1-2 months, until the average number of bacilli per footpad was observed to be at least $5 \times 10^{5}$. At this time the remaining control mice and all treated mice were killed and harvested. Some experiments were observed for 12 months after inoculation.

\section{DETERMINATION OF SERUM RFP CONCENTRATIONS IN SOME GROUPS OF MICE}

Estimation of the concentrations of RFP in the sera of some groups of treated mice was done. The method of determination was described previously by Holmes \& Hilson using an agar diffusion technique for microbiological assay. ${ }^{7}$

\section{Results}

The results of RFP susceptibility testing and minimal effective dosage in 13 strains of $M$. leprae are summarized in Table 1. The results showed that the MED of all strains to RFP were $\leqslant 0.001 \%$ RFP diet, including 5 strains being equal to $0.001 \%, 5 \leqslant 0.0001 \%$, $2 \geqslant 0.0003 \%$ and $1 \leqslant 0.0003 \%$. Five strains of $M$. leprae (patient strain Nos 7, 8, 11, 12 and 13) investigated were also suppressed by $10 \mathrm{mg} / \mathrm{kg}$ RFP dosage once a week by gavage in the experiments. The concentrations of RFP in the sera of mice receiving $0.001,0.003 \%$ RFP diet were $0.13 \sim 0.38 \mu \mathrm{g} / \mathrm{ml}$ and $0.5 \sim 1.6 \mu \mathrm{g} / \mathrm{ml}$. The average level of RFP concentration was $0.21 \mu \mathrm{g} / \mathrm{ml}$ and $0.87 \mu \mathrm{g} / \mathrm{ml}$ respectively.

\section{Discussion}

The first publication by Jacobson \& Hastings ${ }^{8}$ reported a case of a RFP-resistant leprosy patient treated with RFP alone. The evidence was obtained by experiment of mouse footpads. The strain of the $M$. leprae inoculated grew in the footpads of mice which were given $0.001,0.01$ and $0.03 \%$ RFP in the diet. However the organism was inhibited in the 
Table 1. RFP-susceptibility test and MED in 13 strains of $M$. leprae

\begin{tabular}{|c|c|c|c|c|c|c|c|}
\hline \multirow{2}{*}{$\begin{array}{l}\text { Patient } \\
\text { strain } \\
\text { No. }\end{array}$} & \multicolumn{5}{|c|}{ RFP in the mouse diet $(\mathrm{g} \%)$} & \multirow{2}{*}{$\begin{array}{c}\text { RFP } \\
\text { (gavage) } \\
10 \mathrm{mg} / \mathrm{kg}\end{array}$} & \multirow{2}{*}{$\begin{array}{c}\text { MED } \\
(\mathrm{g} / 100 \mathrm{~g})\end{array}$} \\
\hline & 0 & 0.0001 & $0 \cdot 0003$ & $0 \cdot 001$ & 0.003 & & \\
\hline 1 & $8 / 8^{*}$ & $6 / 8$ & $4 / 7$ & $0 / 6$ & $0 / 6$ & ND & $0 \cdot 001$ \\
\hline 2 & $8 / 8$ & $3 / 6$ & $4 / 6$ & $0 / 6$ & $0 / 7$ & ND & 0.001 \\
\hline 3 & $8 / 8$ & $0 / 8$ & $0 / 6$ & $0 / 6$ & $0 / 6$ & ND & $\leqslant 0.0001$ \\
\hline 4 & $8 / 8$ & $0 / 6$ & $0 / 6$ & $0 / 6$ & $0 / 7$ & ND & $\leqslant 0.0001$ \\
\hline 5 & $11 / 11$ & $6 / 8$ & $6 / 8$ & $0 / 8$ & $0 / 6$ & ND & 0.001 \\
\hline 6 & $8 / 8$ & $0 / 6$ & $0 / 6$ & $0 / 6$ & $0 / 6$ & ND & $\leqslant 0.0001$ \\
\hline 7 & $10 / 10$ & $3 / 6$ & ND & $0 / 6$ & $0 / 6$ & $0 / 8$ & $\geqslant 0.0003$ \\
\hline 8 & $7 / 7$ & $0 / 6$ & $0 / 6$ & $0 / 7$ & $0 / 6$ & $0 / 8$ & $\leqslant 0.0001$ \\
\hline 9 & $10 / 10$ & $5 / 5$ & $4 / 8$ & $0 / 7$ & $0 / 7$ & ND & 0.001 \\
\hline 10 & $8 / 10$ & $0 / 8$ & $0 / 6$ & $0 / 8$ & $0 / 6$ & ND & $\leqslant 0.0001$ \\
\hline 11 & $7 / 8$ & $7 / 8$ & $4 / 6$ & $0 / 7$ & $0 / 6$ & $0 / 8$ & 0.001 \\
\hline 12 & $7 / 8$ & ND & $0 / 7$ & $0 / 7$ & $0 / 6$ & $0 / 6$ & $\leqslant 0.0003$ \\
\hline 13 & $10 / 10$ & $6 / 8$ & ND & $0 / 8$ & $0 / 8$ & $0 / 6$ & $\geqslant 0.0003$ \\
\hline
\end{tabular}

Multiplication of $M$. leprae: $\geqslant 10^{5} M$. leprae per footpad.

* No. mice showing multiplication of $M$. leprae. No. mice harvested.

ND, not done.

mice administered $0.06 \%$ RFP diet. As the critical concentration of RFP was not well established, detecting low degree resistance of $M$. leprae was directly influenced. The MED values of RFP reported by experts are variable. Rees et al. ${ }^{9}$ showed that 5 strains of $M$. leprae were suppressed by $0.0025 \%$ RFP diet. Holmes \& Hilson reported 3 strains to MED of RFP, in which 2 strains were $0.001 \%$ and one strain was $0.0003 \%$, they suggested that $0.001 \%$ RFP was the available value for measurement of RFP-resistant organism. Thereafter, Holmes ${ }^{10}$ also reported results of RFP MED for 8 strains of $M$. leprae which were taken from previously untreated lepromatous leprosy patients. Six of the 8 strains were suppressed by $0.001 \%$ RFP in the diet, the remaining 2 strains were $0.0003 \%$ and $0.003 \%$ RFP. Devasundaram et al ${ }^{11}$ presented that the growth of several strains were inhibited by $0.001 \%$ RFP diet, but some strains were not. A report ${ }^{12}$ in China showed that the growth of $M$. leprae in the footpads of mice was suppressed by $0.0001 \%$ RFP in the diet, and $0.001 \%$ RFP exhibited significantly bactericidal activity. The results mentioned above were similar to ours which indicated that MED of RFP for all 13 strains of $M$. leprae were $\leqslant 0.001 \%$ and the majority of these strains were $<0.001 \%$. It is possible that MED level of RFP was lower than that of other countries. In addition, 5 of the 13 strains were also inhibited by $10 \mathrm{mg} / \mathrm{kg}$ RFP (equal to $0.0005 \%$ RFP) once a week by gavage. Shepard $^{2}$ reported that no antileprosy activity to 0.001 and $0.0001 \%$ RFP for M. leprae were observed. However, the bactericidal action was found using $0.01 \%$ RFP in the diet. Guelpa-Lauras et al. ${ }^{13}$ reported 9 cases of RFP-resistant leprosy. The evidence was obtained by experiments of mouse footpad, which multiplication of $M$. leprae were found in mice administered $10 \mathrm{mg} / \mathrm{kg}$ RFP once a week by gavage. The data mentioned above suggested the MED values of RFP differ among the reports.

The studies have been performed to determine sera RFP concentrations in some groups of treated mice infected with $M$. leprae, the results were similar to that of Holmes' report, which showed that the RFP concentrations in the diet were correct. 


\title{
References
}

1 Levy L et al. The bactericidal effect of rifampicin on M. leprae in man: (a) Single doses of 600, 900 and 1200 mg; (b) Daily doses of 300 mg. Int J Lepr, 1976; 44: 183.

2 Shepard CC. Further experience with the rapid bactericidal effect of rifampin on M. Leprae. Am J Trop Med Hyg, 1974; 23: 1120.

3 Levy L. The normal mouse in experimental chemotherapy. Int J Lepr, 1987; 55(4 suppl): 843.

4 Ji Baohong. Drug susceptibility of Mycobacterium leprae. Int J Lepr, 1987; 55(4 suppl): 830.

${ }^{5}$ Wang Heying et al. An experimental model of mouse footpads infected with $M$. leprae. J Dermatological Prevention Therapy Research, 1977; 3: 168.

6 Wang Heying et al. Preliminary observation on efffect of thymic peptide in experimental infection of mice with M. leprae. Acta Acad Med Sci, 1985; 7: 227.

${ }^{7}$ Holmes LB, Hilson GHF et al. The effect of rifampicin and dapson on experimental mycobacterium leprae infections: minimum inhibitory concentrations and bactericidal action. J Med Microbial, 1972; 5: 251.

8 Jacobson RR, Hastings RC. Rifampin-resistant leprosy. Lancet, 1976; ii: 1304.

9 Rees RJW. Experimental and clinical studies on rifampin in treatment of leprosy. $\mathrm{Br} \mathrm{Med} J, 1970 ; 5688: 89$.

10 Holmes LB. Minimum inhibitory and bactericidal dosages of rifampicin against mycobacterium leprae in the mouse footpad: Relationship to serum rifampicin concentrations. Int J Le pr, 1974; 42: 289.

11 Devasundaram B et al. Plasma rifampicin levels in mice: a preliminary report. Int J Lepr, 1989; 57( 1 suppl): 379. (Abstract.)

12 Ji Baohong et al. Study on experimentalchemotherapy of mouse footpads infected with M. leprae. Chinese J Derm, 1980; 13: 24.

13 Guelpa-Lauras, Claire-Cecile et al. Nine cases of rifampicin-resistant leprosy. Int J Lepr, 1984; 52: 101.

\section{Etude de la sensibilité de 13 souches du bacille de Hansen Mycobacterium leprae à la rifampicine et détermination d'une dose minimale efficace.}

\author{
WANG HEYING, LI WENZHONG, YE GANYUN, YU LINCHONG ET SHI MEIQIN
}

Résumé Une étude de sensibilité à la rifampicine (RFP) de 13 souches du Mycobacterium leprae fut menée sur le coussinet plantaire de la souris ainsi que la détermination d'une dose minimale efficace (MED). Parmi ces souches du $M$. leprae, 8 furent obtenues de patients pluribacillaires non traités précédemment et 5 de lépreux récidivant qui n'avaient pas été traités à la RFP. Les résultats ont prouvé que la MED de toutes les souches sensibles à la RFP étaient $\leqslant 0,001 \%$ de RFP dans l'alimentation, 5 souches étant égales à $0,001 \%, 5 \leqslant 0,0001 \%$, $2 \geqslant 0,0003 \%$ et $1 \leqslant 0,0003 \%$. Les résultats indiquaient que la valeur de la MED de la RFP pouvait être inférieure à celle indiquée dans d'autres rapports. Etant donné que la concentration critique de RFP permettant d'évaluer les souches résistantes à la RFP n'est pas bien connue, une autre étude s'avèrerait utile. Les résultats de la détermination des concentrations de sérums RFP chez les souris ayant reçu un régime de RFP étaient identiques à ceux du rapport de Holmes. Une élévation du nombre des bacilles avait été supprimée dans 5 des 13 souches en administrant $10 \mathrm{mg} / \mathrm{kg}$ de RFP par gavage.

\section{El test de susceptibilidad de 13 cepas de Mycobacterium leprae a la rifampicina y la determinación de la dosificación ef ectiva mínima.}

\author{
WANG HEYING, LI WENSHONG, YE GANYUN, YU LINCHONG Y SHI MEIQIN
}

Resumen Se llevó a cabo el test de la susceptibilidad a la rifampicina (RFP) y la determinación de la dosificación efectiva mínima (MED) en 13 cepas de Mycobacterium leprae mediante el uso de la técnica del cojincillo del pié de ratón. Entre estas cepas de $M$. leprae, 8 fueron obtenidas de pacientes leprosos multibacilares no tratados previamente y 5 de pacientes leprosos con recaída sin haber usado RFP previamente. Los resultados mostraron que la MED de todas las cepas a RFP fue de $\leqslant 0,001 \%$ de RFP en la dieta, 5 cepas siendo iguales a $0,001 \%, 5 \leqslant 0,0001 \%, 2 \geqslant 0,0003 \%$ y $1 \leqslant 0,0003 \%$. Los resultados indicaron que el valor de MED de RFP sería menor que lo informado por otros trabajos. Debido a la concentración crítica de RFP para la valoración de las cepas resistentes a RFP no está bien establecido si vale la pena un estudio posterior. Los resultados de la determinación de las concentraciones de RFP en el suero en ratones administrados con dieta con RFP fueron idénticos a aquellos informados por Holmes. Cinco de las 13 cepas mostraron también que el crecimiento de los bacilos fue detenido con $10 \mathrm{mg} / \mathrm{kg}$ de RFP usando el método de gavaje. 